\title{
BIOLOGICAL CHARACTERISTICS OF PIGS TRANSGENIC FOR HUMAN GROWTH HORMONE
}

\author{
L.K. Ernst ${ }^{1}$, N.A. Zinovieva', N.A. Volkova', A.Yu. Filimonov' ${ }^{2}$, I.A. Ralkov', \\ I.V. Gusev', G. Brem ${ }^{3}$ \\ ${ }^{1}$ All-Russia Research and Development Institute for Livestock Husbandry, RAAS, Dubrovitsy settlement 142132, Moscow province, Russia \\ e-mail: $n$ zinovieva@mail.ru \\ ${ }^{2}$ N.I. Pirogov Russian National Research Medical University, Moscow 117997, Russia \\ e-mail: aleks_ariah@mail.ru \\ ${ }^{3}$ Institute of Animal Husbandry and Animal Welfare of the University of Veterinary Medicine, Vienna A-1210, Austria \\ e-mail: gottfried.brem@agrobiogen.de
}

Received January 15, 2013

Sum mary

The increase of growth hormone expression in pigs transgenic for WAP-hGH gene construct of $\mathbf{F}_{3}$ (non-pregnant and lactating sows) and $F_{5}$ generations (young gilts in age of 5 and 9 months) was observed. The alteration of some biochemical characteristics of blood serum in transgenic pigs comparing to control animals was detected. The differences in correlation relationships between some biochemical characteristics of transgenic and control pigs were established.

Keywords: transgenic pigs, growth hormone, biochemical characteristics, correlation.

One of prior targets of modern biotechnology is creation of transgenic animals that have predetermined productive and biological properties, or produce bioactive substances $(1,2)$. To provide the directional synthesis of recombinant proteins in the mammary gland, the designed gene constructs include regulatory elements of milk protein genes $-\kappa$-casein, $\beta$-lactoglobulin, $\alpha$ lactalbumin, whey acidic protein (WAP) (3); in several such studies it was observed the unspecific expression of gene constructs associated with WAP promoter. Thus, C.W. Pittius et al. (4) detected mRNA of human tissue plasminogen activator in a tongue, kidneys, and salivary glands of transgenic mice. The expression of human growth hormone (hGH) controlled by mouse WAP promoter of 2,6 kb length was found in the serum of lactating transgenic mice (5). According W.H. Güenzburg et al. (6), 40\% transgenic mice - carriers of the integrated hGH gene construct with WAP-promoter of 2,4 kb length, showed the expression of the specific mRNA in salivary glands and testes. In all the transgenic mice the transgenic protein was synthesized in brain cells. In this case, non-specific expression of genes introduced into the genome under the control of WAP-promoter resulted from non-specific expression of the endogenous WAP.

A great number of various studies on transgenesis yet haven't revealed all the factors determining the efficiency of expression of foreign genes in host's cells. Even in early period of research it was clear that interaction of an introduced gene construct and a host genome is more complex than just a simple summation of different determinants. Since the nature of introduced foreign genes is similar to mutation (insertion), transgenic animals may expectedly develop many unpredictable traits caused by modification and mutation, because each mutation involves not a single process for a single trait but a certain group of developmental processes (7). This assumption was proved by experiments on different transgenic animals (8-11). Therefore, evaluation of transgene effects in the organism is quite topical issue for both biotechnology and breeding.

In this work the authors studied the expression of the introduced gene and its effect on physiological and morphological traits of transgenic pigs of $\mathrm{F}_{3}$ and $\mathrm{F}_{5}$ generations.

Technique. The object of research were pigs transgenic for human growth hormone gene construct controlled by the mouse WAP-promoter (WAP-hGH). Biological and economically useful traits of the animals were studied in conditions of physiological yard of the All-Russia Research and Development Institute for Livestock Husbandry; the groups were formed based on the principle of one-litter analogs.

GH content in the blood serum of pigs of $\mathrm{F}_{3}$ (not-pregnant "dry" and lactating sows) and $\mathrm{F}_{5}$ generations (young pigs aged 5 and 9 months) was determined by ELISA on immunoreader Dinatech ("Dynex Technologies", USA) using C-kit ("Sigma-Aldrich", USA) according to manufacturer's instructions. The expression of GH in organs and tissues was assessed immunohistochemically using ABC-kit ("VectorLabs", UK) following the manufacturer's recommendations. HGH-specific antibodies ("Sigma-Aldrich", USA) were used as first antibodies. The product of immunohistochemical reaction was detected with 3,3-diaminobenzidine tetrachloride (DAB) ("VectorLabs", UK). Biochemical parameters of the blood were determined in 7-months-old pigs of $\mathrm{F}_{5}$ generation using conventional techniques $(12,13)$.

The obtained data were statistically treated with biometric methods for small samples (14).

Results. GH level in the blood of non-pregnant "dry" and lactating transgenic sows of $F_{3}$ was 3,3-3,5 times higher than in control animals. In young pigs of $\mathrm{F}_{5}$ at the age of 5 months $\mathrm{GH}$ level exceeded control 2,25 times, and at the age of 9 months $-3,77$ times. It's notable that control young animals showed no differences in GH level at different age periods, while their experimental transgenic analogs showed the growth of GH level in 2,0 times (Table 1). 
1. Growth hormone level $(\mathrm{GH}, \mathrm{ng} / \mathrm{ml})$ in the blood of transgenic (experiment) and nontransgenic (control) sows $\left(\mathbf{F}_{3}\right)$ and young animals $\left(\mathbf{F}_{5}\right)$ of different age $(X \pm x)$

\begin{tabular}{|c|c|c|c|c|}
\hline Group & & riment & \multicolumn{2}{|c|}{ Control } \\
\hline Lactating sows & $n=10$ & $29,00 \pm 1,7^{\mathrm{a}, \mathrm{b}}$ & $n=10$ & $8,30 \pm 1,9^{b}$ \\
\hline Non-pregnant "dry" sows & $n=10$ & $24,00 \pm 1,2^{\mathrm{a}, \mathrm{b}}$ & $n=10$ & $7,30 \pm 0,8^{\mathrm{c}}$ \\
\hline \multicolumn{5}{|l|}{ Young animals: } \\
\hline age 5 months & $n=3$ & $1,53 \pm 0,2$ & $n=3$ & $0,68 \pm 0,3$ \\
\hline age 9 months & $n=3$ & $3,10 \pm 0,9$ & $n=3$ & $0,65 \pm 0,3$ \\
\hline
\end{tabular}

The study of GH synthesis in organs and tissues of lactating transgenic sows of $\mathrm{F}_{3}$ revealed the expression of GH in the mammary glands, pancreas, salivary gland and the pituitary, as well as the absence of this process in the heart, liver, kidneys, lungs and muscle tissue. So, organs and tissues of transgenic animals contained the higher level of GH, and the most intense synthesis of $\mathrm{GH}$ was observed in transgenic lactating sows. The presence of GH in the pancreas, salivary glands, and pituitary indicates nonspecific expression caused by WAP-promoter. In general, the obtained data may be the evidence that transgenic pigs have higher activity of anabolic processes compared with control animals.

In young pigs of $\mathrm{F}_{5}$, the levels of metabolic products in the blood serum of transgenic and control pigs were within the physiological norm.

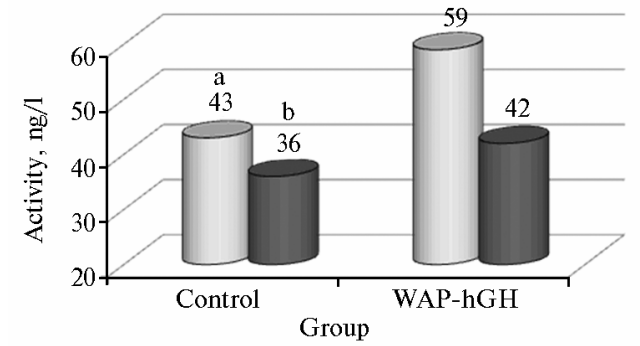

Fig. 1. Activity of alanine aminotransferase (a) and aspartate aminotransferase (b) in the blood of control and transgenic pigs of $\mathbf{F}_{5}$ generation. The introduced gene construct WAP-hGH (human growth hormone gene controlled by mouse WAP-promoter).
The most significant changes were associated with the activity of aminotransferases - alanine aminotransferase and aspartate aminotransferase (ALT and AST). ALT level in transgenic animals was $37,2 \%$ higher than that in control analogs. The activity of ALT was positively correlated with glucose content in the blood serum, which in transgenic pigs was $8,8 \%$ higher than in control animals. The activity of AST in the blood serum of experimental group also exceeded (16,7\%) the control (Fig. 1). The trend to growth of AST activity in transgenic pigs may be the evidence of more intense metabolism of protein and energy in the liver and muscle tissue of these animals.

$\mathrm{GH}$ is one of regulators of lipid metabolism, and its increased production stimulates the transfer of lipids from the periphery to the liver. Knowing about the differences in GH blood level of control and transgenic pigs, the latter can be expected to have changes in lipid metabolism. Total lipids and fat components in the blood serum of transgenic and control animals of $F_{5}$ (Table 2) were found to be within physiological norms in both groups, though transgenic pigs had 5,6\% higher level of total lipids than control animals due to higher content of cholesterol ether.

2. Total lipids and fat components in the blood serum of transgenic (experiment) and non-transgenic (control) young fattening pigs of $\mathbf{F}_{5}(X \pm x)$

\begin{tabular}{|c|c|c|c|c|}
\hline Character & $\begin{array}{l}\text { Control } \\
(n=6)\end{array}$ & $\begin{array}{l}\text { Experiment } \\
(n=3)\end{array}$ & $\begin{array}{l}\text { Difference } \\
\text { "experiment-control" }\end{array}$ & $\begin{array}{l}\text { Experiment to } \\
\text { control, } \%\end{array}$ \\
\hline Total lipids, $\mathrm{g} \%$ & $0,40 \pm 0,01$ & $0,38 \pm 0,02$ & 0,02 & 5,6 \\
\hline \multicolumn{5}{|l|}{ Fat components, $\%$ : } \\
\hline phospholipids & $11,9 \pm 0,2$ & $10,5 \pm 0,2$ & $-1,50$ & $-12,5$ \\
\hline mobile + deposited glycerides & $2,2 \pm 0,2$ & $1,5 \pm 0,1$ & $-0,70$ & $-30,9$ \\
\hline cholesterol & $3,6 \pm 0,3$ & $2,4 \pm 0,1$ & $-1,20$ & $-32,0$ \\
\hline free cholesterol & $37,7 \pm 0,3$ & $44,4 \pm 0,3$ & 6,80 & 17,9 \\
\hline triglyceride & $38,3 \pm 0,2$ & $35,6 \pm 0,0$ & $-2,70$ & $-6,9$ \\
\hline non-etherified fatty acids & $5,9 \pm 0,2$ & $5,4 \pm 0,1$ & $-0,50$ & $-8,5$ \\
\hline
\end{tabular}

Transgenic pigs exhibited a trend to decrease in the percentage content of all fat components (except cholesterol ether) compared with control animals, possibly due to the increased functional activity of GH that promotes the transfer of peripheral of lipids to the liver where occurs active hydrolysis of lipids to form glycerol and fatty acids, and their utilization as energy substrate.

Experimental animals also showed increased levels of polyunsaturated fatty acids - linoleic, A-linoleic and arachidonic acid. In particular, the total content of these fatty acids in control individuals was $7,90 \%$, while in transgenic pigs this value was $1,96 \%$ higher (due to higher content of each of the abovementioned fat components) (Fig. 2). 


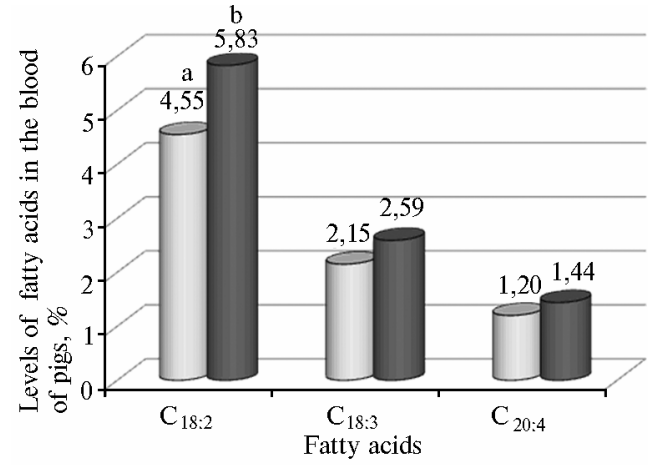

Fig. 2. Levels of polyunsaturated fatty acids in the blood serum of control and transgenic pigs of $F_{5}$ generation. $\mathrm{C}_{18: 2}$ - linoleic acid, $\mathrm{C}_{18: 3}$ - A-linoleic acid, $\mathrm{C}_{20: 4}$ - arachidonic acid. Gene construct WAPhGH (human growth hormone gene controlled by mouse WAP-promoter). control pigs were found to be significantly changed by the integrated gene construct in respect to GH synthesis and earlier existing correlations (Table 3). As it can be seen from Table 3, in 6 of the 13 pairs of biochemical traits, there was the negative correlation coefficient of transgenic and control animals. For example, the coefficient of correlation between serum creatinine and creatinine kinase in transgenic pigs was $-0,64$, while in control animals $+0,58$. The correlation between glucose and insulin levels was, respectively, $+0,49$ and $-0,13$. Even if the sign of the correlation coefficient was similar in both groups, in most cases this value was significantly lower in transgenic animals compared with control analogs. Thus, the correlation coefficient for the content of total protein and blood urea in transgenic pigs was $-0,46$, while in control animals $-0,83$; glucose and triglycerides - respectively, $-0,66$ and -0,99; amylase and glucose - respectively $+0,03$ and $+0,52$.

\section{Correlations between biochemical parameters of the blood in transgenic (experiment)} and non-transgenic (control) pigs (generations $F_{3}$ and $F_{5}$ )

\begin{tabular}{l|c|c}
\hline \multicolumn{1}{c}{ Compared pair of parameters } & \multicolumn{2}{c}{ Coefficient of correlation $r$} \\
\cline { 2 - 3 } & experiment & control \\
\hline Creatinine-creatinine kinase & $-0,64$ & $+0,58$ \\
Total protein - urea & $-0,46$ & $-0,83$ \\
Glucose -insulin & $+0,43$ & $-0,13$ \\
Glucose - triglycerides & $-0,66$ & $-0,99$ \\
AST-total protein & $+0,50$ & $+0,50$ \\
ALT-total protein & $+0,51$ & $+0,21$ \\
Thyroxin-urea & $-0,66$ & $-0,78$ \\
Thyroxin-insulin & $-0,39$ & $+0,02$ \\
Amylase-glucose & $+0,03$ & $+0,52$ \\
Triiodothyronine-thyroxin & $+0,10$ & $-0,76$ \\
Lactate dehydrokinase-cholesterol & $-0,87$ & $+0,33$ \\
Cortisol-urea & $+0,01$ & $+0,88$ \\
Lactate dehydrokinase -lactic acid & $+0,39$ & $-0,07$ \\
\hline N o t e . AST - aspartate aminotransferase, ALT - alanine aminotransferase. & & \\
\hline
\end{tabular}

On the general, it can be assumed that the integrated gene construct WAP-hGH provided modifications of certain phenotypic characteristics and significant changes in direction and value of metabolic correlations in the animal organism. This serves as a definite advantage for selection, because the established correlations ensure stability of the organism and prevent its alteration.

The obtained results show that the high level of growth hormone in the blood of transgenic pigs can not be completely realized in a normal organism as its other metabolic mechanisms associated with growth hormone remain unchanged. For example, the high blood level of growth hormone may contradict the amount of receptors to it.

The presented data confirm the theory of I.I. Schmalhausen about the organism as the integrated system in individual and historical development. "Since all organs of an animal form a single system whose parts depend on each other, co-operate and contradict to each other; no change happens in one part of the organism without any corresponding changes in all other parts".

Thus, transgenic animals manifest changes of the earlier existing "normal" metabolic correlations, which, undoubtedly, influences their individual development. Integration and subsequent expression of foreign genes significantly affects the nature metabolism and the value of important biochemical parameters. The role of these factors in the development of economically valuable traits is hard to predict, and the authors hope to reveal it in further researches.

\section{REFERENCES}

1. Brem G., Zinov'eva N.A., Ernst L.K. Sel'skokhozyaistvennaya Biologiya [Agricultural Biology], 1993, 6: 3-27.

2. Ernst L.K., Brem G., Zinov'eva N. Zootekhniya, 1994, 5: 2-4.

3. Ernst L.K., Zinov'eva N.A., Brem G. Sovremennoe sostoyanie i perspektivy ispol'zovaniya transgennykh tekhnologii v zhivotnovodstve [Modern State of Transgenics and Prospects for Its Use in Animal Husbandry]. Moskva, 2002.

4. Pittius C.W., Hennighausen L., Lee E., Westphal H., Nicols E., Vitale J. A milk protein gene promoter directs the expression of human tissue plasminogen activator cDNA to the mammary gland in transgenic mice. PNAS USA, 1988, 85: 5874-5878.

5. Reddy V.B., Vitale J.A., Wei C., Montoya-Zavala M., Stice S.L., Balise J., Robi J.M. Expression of human growth hormone in the milk of transgenic mice. Anim. Biotechnol., 1991, 2: 15-29.

6. Günzburg W.H., Salmons B., Zimmermann B., Müller M., Erfle V., Brem G. A mammary specific promoter directs expression of growth hormone not only to the mammary gland, but also to Bergman Glia cells in transgenic mice. Mol. Endocrinol., 1991, 5: 123-133.

7. Shmal'gauzen I.I. Faktory evolyutsii (teoriya stabiliziruyushchego otbora) [Factors of Evolution. The Theory of Stabilizing Selection]. Moskva-Leningrad, 1946.

8. Mehtali N., LeMeur V., Lathe R. The methylation-free status of a houskeeping transgene is lost at high copy number. Gene, 1990, 91: 179-184.

9. Brem G., Brenning B., Salamons B. et al. Unerwartets transgene Expression eines gesaengespezifischen Wachstumshormon Genkonstruktes in den Bergmann- 
Gliazellen der Maus. Tiwrarztl. Prax., 1991, 19: 1-6.

10. Klenovitskii P.M., Nekrasov A.A. Aktual'nye problemy razvitiva zhivotnovodstva [Topical Issues of Animal Husbandry]. Dubrovitsy, 1998: $184-191$.

11. Kalashnikova L.A. Ispol'zovanie DNK-tekhnologii dlya otsenki i izmeneniya genoma sel'skokhozyaistvennykh zhivotnykh. Avtoreferat doktorskoi dissertatsii [The Use of DNA Technology for Assessment and Measurement of the Genome of Agricultural Animals. Extended Abstract of Doct. Sci. Dissertation]. Lesnye Polyany, 1998.

12. Kudryavtsev A.A., Kudryavtseva L.A. Klinicheskaya gematologiya zhivotnykh [Clinical Hematology of Animals]. Moskva, 1974.

13. Kondrakhin I.P., Arkhipov A.V., Levchenko V.I., Talanov G.A., Frolova L.A., Novikov V.E. Metody veterinarnoi klinicheskoi laboratornoi diagnostiki: Spravochnik/Pod redaktsiei I.P. Kondrakhina [Methods of Veterinary Clinical Laboratory Diagnostics: a Reference Book. I.P. Kondrakhin (ed.)]. Moskva, 2004.

14. Merkur'eva E.K. Biometriya v selektsii i genetike sel'skokhozyaistvennyi zhivotnykh [Biometrics in the Selection and Genetics of Farm Animals]. Moskva, 1970. 